\title{
Pengembangan Kapasitas Manajemen LKSA Guyub Rukun Kota Bengkulu
}

\author{
Yessilia Osira ${ }^{1^{*}}$ dan Nurlianti Muzni ${ }^{2}$ \\ 1 Jurusan Kesejahteraan Sosial FISIP Universitas Bengkulu \\ ${ }^{2}$ Ilmu Komunikasi FISIP Universitas Bengkulu
}

\section{ARTICLE INFO}

Riwayat Artikel:

Draft diterima: 17 November 2021

Revisi diterima: 06 Desember 2021

Diterima: 13 Desember 2021

Tersedia Online: 27 Desember 2021

Corresponding author:

*yosira@unib.ac.id

Citation: Osira. Y, dan Muzni. N. 2021. Pengembangan Kapasitas Manajemen LKSA Rukun Kota Bengkulu. ICOMES: Indonesian Journal of Community Empowerment and Service. 1(1), pp: 30-34

\begin{abstract}
ABSTRAK
Pengembangan Kapasitas Manajemen LKSA Guyub Rukun Kota Bengkulu. Pengembangan kapasitas pada dasarnya merupakan suatu proses, yang dilaksanakan pada tiga tingkatan, yaitu individu, kelompok dan institusi atau organisasi, dalam hal ini LKSA Guyub Rukun. Proses tersebut dilakukan untuk menjamin kesinambungan organisasi melalui pencapaian tujuan dan sasaran organisasi yang bersangkutan. Berkaitan dengan hal tersebut, maka kegiatan pengabdian kepada masyarakat yang dilakukan sebagai bentuk tindak lanjut kesepakatan kerjasama antara Fakultas Ilmu Sosial dan Ilmu Politik Universitas Bengkulu dengan LKSA Guyub Rukun Kota Bengkulu ini bertujuan 1) Membantu Pengurus LKSA Guyub Rukun dalam pengelolaan administrasi kegiatan lembaga. 2) Membantu Pengurus LKSA Guyub Rukun dalam melakukan penjadwalan berbagai kegiatan anak-anak di lembaga. 3) Membantu Pengurus LKSA Guyub Rukun dalam mempersiapkan proses pelaksanaan akreditasi lembaga. Hasil kegiatan pengabdian pada akhirnya merupakan wujud pendampingan proses akreditasi yang dilaksanakan oleh LKSA Guyub Rukun, yang meliputi penilaian terhadap 6 standar akreditasi: standar 1 (pelayanan terhadap warga binaan), standar 2 (proses pelayanan praktek pekerja sosial), standar 3 (manajemen organisasi), standar 4 (sumber daya manusia), standar 5 (sarana dan prasarana, dan standar 6 (hasil pelayanan lembaga).
\end{abstract}

Kata kunci: Pengembangan kapasitas, manajemen LKSA, akreditasi

\begin{abstract}
Development of Management Capacity of LKSA Guyub Rukun Bengkulu City. Capacity building is a process, which is carried out at three levels, namely individuals, groups, and institutions or organizations, in this case, the LKSA Guyub Rukun. This process is carried out to ensure the continuity of the organization through the achievement of the goals and objectives of the organization concerned. In this regard, the community service activities carried out as a form of follow-up to the cooperation agreement between the Faculty of social and Political Sciences, Bengkulu University, and LKSA Guyub Rukun Bengkulu City, have the following objectives: 1) Assist the LKSA Guyub Rukun Management in managing the administration of the institution's activities. 2) Assist the LKSA Guyub Rukun Management in scheduling various children's activities at the institution. 3) Assist the LKSA Guyub Rukun Management in preparing the process of implementing institutional accreditation. The results of service activities are ultimately a form of assistance in the accreditation process carried out by LKSA Guyub Rukun, which includes an assessment of 6 accreditation standards: standard 1 (services to inmates), standard 2 (the process of social worker practice service), standard 3 (organizational management), standard 4 (human resources), standard 5 (facilities and infrastructure, and standard 6 (outcomes of institutional services).
\end{abstract}

Keywords: Capacity building, LKSA management, accreditation

\section{PENDAHULUAN}

Pengembangan kapasitas dalam kegiatan pengabdian kepada masyarakat di Lembaga Kesejahteraan Sosial Anak (LKSA) Guyub Rukun ini dipahami sebagai upaya meningkatkan kemampuan, keterampilan, pemahaman, sikap, nilai-nilai, hubungan, perilaku, motivasi, sumber daya, dan kondisi-kondisi yang memungkinkan setiap individu, organisasi, jaringan kerja/sektor, dan sistem yang lebih luas untuk melaksanakan fungsi-fungsi mereka dan mencapai tujuan pembangunan yang telah ditetapkan dari 
waktu ke waktu, dalam hal ini adalah perlindungan sosial bagi anak-anak (Anni Millen;2004).

Kegiatan ini dilaksanakan sebagai tindak lanjut Perjanjian Kerja Sama antara Fakultas Ilmu Sosial dan Ilmu Politik (FISIP) Universitas Bengkulu (Unib) dengan LKSA Guyub Rukun Kota Bengkulu pada 2020. Pada tahun 2021, Tim Pengabdian Unib melakukan kegiatan Pengembangan Kapasitas Manajemen LKSA, khususnya terkait pendampingan lembaga dalam mengikuti proses akreditasi. Dalam kegiatan tersebut, Tim Pengabdian melakukan berbagai upaya bersama-sama Pengurus LKSA Guyub Rukun dalam menyiapkan aspek-aspek penilaian lembaga meliputi: standar 1 (pelayanan terhadap warga binaan), standar 2 (proses pelayanan praktek pekerja sosial), standar 3 (manajemen organisasi), standar 4 (sumber daya manusia), standar 5 (sarana dan prasarana, dan standar 6 (hasil pelayanan lembaga).

Hasil wawancara dengan Pengurus LKSA Guyub Rukun sebelumnya menunjukkan bahwa lembaganya masih terakreditasi C pada tahun 2019 ini, masih mengalami banyak hambatan atau keterbatasan dalam menjalankan operasional pengasuhan anak. Berbagai hambatan tersebut pada dasarnya bersumber pada kurangnya sumber daya manusia yang memahami manajemen LKSA sebagai upaya perlindungan sosial anak, termasuk secara praktis mengalami hambatan dalam meningkatkan statusl akreditasi lembaga. Wujud nyata dari keterbatasan atau hambatan tersebut dianataranya: 1) kurang tertatanya pengelolaan administrasi panti, 2) Belum terjadwalkannya berbagai kegiatan anak-anak secara sistematis dan berkesinambungan, 3) Belum siapnya lembaga dalam menghadapi proses akreditasi LKSA.

Padahal pasal 1 Permensos Nomor 17 tahun 2012, menjelaskan bahwa akreditasi adalah penetapan tingkat kelayakan dan standardisasi Lembaga di bidang Kesejahteraan Sosial yang didasarkan pada penilaian program, sumberdaya manusia, organisasidan manajemen, sarana dan prasarana, dan hasil pelayanan kesejahteraan sosial. Proses ini akan menghasilkan tingkatan LKSA dengan akreditasi baik sekali atau A, akreditasi baik atau B, dan akreditasi cukup atau C.

Akreditasi juga merupakan upaya untuk mengkaji implementasi Kebijakan Standar Pelayanan Berbasis Lembaga Kesejahteraan Sosial Anak (LKSA) yang termuat dalam Permensos RI No. 30/HUK/2011 tentang Standar Nasional Pengasuhan Anak Untuk Lembaga Kesejahteraan Sosial Anak yang berisikan instrumen kebijakan yang 31 bertujuan untuk menjamin dan memenuhi hak-hak anak terlantar yang berada di dalam panti (Wijayanti Retno dkk, 2015).

Oleh Karena itu, pengembangan kapasitas Manajemen LKSA Guyub Rukun yang dilakukan dalam kegiatan pengabdian ini tidak saja pada penyiapan materi, namun juga pendampingan saat pelaksanaan akreditasi. Melalui proses pengembangan kapasitas tersebut, diharapkan LKSA Guyub Rukun mendapatkan penilaian "B" dari proses akreditasi yang dilakukan. Berdasarkan latar belakang tersebut, maka rumusan masalah kegiatan pengabdian kepada masyarakat ini adalah "Bagaimana Pengembangan Kapasitas Manajemen Lembaga Kesejahteraan Sosial Anak (LKSA) Guyub Rukun Kota Bengkulu." Rumusan masalah tersebut dapat diterjemahkan kedalam berbagai sub-sub masalah sebagai berikut: 1) Bagaimana pengelolaan administrasi LKSA Guyub Rukun ? 2) Bagaimana penjadwalan berbagai kegiatan anak-anak LKSA Guyub Rukun? 3) Bagaimana kesiapan LKSA Guyub Rukun dalam menghadapi proses akreditasi LKSA?

Kegiatan pengabdian kepada masyarakat ini diharapkan dapat mengembangkan kapasitas Manajemen LKSA Guyub Rukun. Secara khusus, kegiatan ini bertujuan: 1) Membantu Pengurus LKSA Guyub Rukun dalam pengelolaan administrasi kegiatan lembaga. 2) Membantu Pengurus LKSA Guyub Rukun dalam melakukan penjadwalan berbagai kegiatan anak-anak di lembaga. 3) Membantu Pengurus LKSA Guyub Rukun dalam mempersiapkan proses pelaksanaan akreditasi lembaga.

\section{TINJAUAN PUSTAKA}

UNDP (United Nation of Development Programme) dan CIDA (Canadian International Development Agency) dalam Milen (2004) memberikan pengertian peningkatan kapasitas sebagai: proses dimana individu, kelompok, organisasi, institusi, dan masyarakat melaksanakan tugas pokok dan fungsi (core functions), memecahkan permasalahan, merumuskan dan mewujudkan pencapaian tujuan yang telah ditetapkan, dan 2) Memahami dan memenuhi kebutuhan pembangunan dalam konteks yang lebih luas dalam cara yang berkelanjutan.

Hal ini sejalan dengan konsep pengembangan kapasitas menurut Grindle (1997) yang menyatakan bahwa pengembangan kapasitas sebagai ability to perform appropriate task effectvely, efficiently and sustainable. Bahkan Grindle menyebutkan bahwa pengembangan kapasitas mengacu kepada improvement in the ability of public sector organizations. 
Berdasarkan pengertian di atas, Imam Hardjanto (2006) menyebutkan tiga faktor kesamaan pengertian tentang pengembangan kapasitas, meliputi: 1) Pengembangan kapasitas merupakan suatu proses, 2) Proses tersebut harus dilaksanakan pada tiga tingkatan, yaitu individu, kelompok dan institusi atau organisasi, dan 3) Proses tersebut dimaksudkan untuk menjamin kesinambungan organisasi melalui pencapaian tujuan dan sasaran organisasi yang bersangkutan, dalam hal ini adalah LKSA Guyub Rukun Kota Bengkulu.

\section{METODE PELAKSANAAN}

Berdasarkan rumusan masalah, potensi dan kemampuan yang ada, maka upaya pemecahan masalah akan dilaksanakan melalui kerangka pengembangan kapasitas LKSA Guyub Rukun. Upaya pemecahan masalah yang akan dilakukan dirincikan pada Tabel 1 :

Tabel 1. Metode Pelakasanaan Kegiatan Pengabdian

\begin{tabular}{|c|c|c|}
\hline Aspek Kegiatan & Sasaran & $\begin{array}{c}\text { Indikator } \\
\text { keberhasilan }\end{array}$ \\
\hline $\begin{array}{l}\text { Pengadministras } \\
\text { ian LKSA }\end{array}$ & $\begin{array}{l}\text { - Penyusunan } \\
\text { Profil LKSA } \\
\text { - Penyusunan } \\
\text { profil klien dan } \\
\text { pengurus LKSA } \\
\text { - Pembelian } \\
\text { sarana-prasara } \\
\text { na administrasi }\end{array}$ & $\begin{array}{l}\text { - Tersusunnya } \\
\text { profil LKSA } \\
\text { Guyub Rukun } \\
\text { - Tersusunnya } \\
\text { profil klien } \\
\text { dan } \\
\text { pengurus } \\
\text { LKSA } \\
\text { - Tersedianya } \\
\text { ATK }\end{array}$ \\
\hline $\begin{array}{l}\text { Penjadwalan } \\
\text { kegiatan LKSA }\end{array}$ & $\begin{array}{l}\text { - Penyusunan } \\
\text { jadwal kegiatan } \\
\text { harian LKSA } \\
\text { Panti Asuhan } \\
\text { Guyub Rukun }\end{array}$ & $\begin{array}{l}\text { - } \text { Tersusun dan } \\
\text { terlaksanaka } \\
\text { nnya jadwal } \\
\text { harian } \\
\text { kegiatan } \\
\text { LKSA } \\
\end{array}$ \\
\hline $\begin{array}{l}\text { Pelaksanaan } \\
\text { Akreditasi LKSA }\end{array}$ & $\begin{array}{l}\text { Penyusunan } \\
\text { dokumen } \\
\text { kelengkapan } \\
\text { akreditasi LKSA } \\
\text { Guyub Rukun }\end{array}$ & $\begin{array}{l}\text { - Tersusunnya } \\
\text { dokumen } \\
\text { kelengkapan } \\
\text { akreditasi } \\
\text { LKSA Guyub } \\
\text { Rukun } \\
\text { - Terlaksanany } \\
\text { a akreditasi } \\
\text { LKSA Guyub } \\
\text { Rukun }\end{array}$ \\
\hline
\end{tabular}

\section{HASIL DAN PEMBAHASAN}

Kegiatan pengabdian ini dilakukan dengan pendekatan pengembangan kapasitas LKSA Guyub Rukun Kota Bengkulu. Secara teknis, kegiatan pengabdian ini dilaksanakan dengan teknik sebagai berikut.
Kegiatan peningkatan kapasitas pengurus LKSA Guyub Rukun Kota Bengkulu tentang pengadministrasian lembaga dan persiapan akreditasi LKSA. Kegiatan ini dilakukan melalui proses diskusi kelompok terfokus, yang dilanjutkan dengan pemberian materi tentang materi-materi yang perlu disiapkan LKSA Guyub Rukun dalam menghadapi proses akreditasi lembaga. Pendokumentasian kegiatan ini dapat dilihat pada gambar 1 dibawah ini:

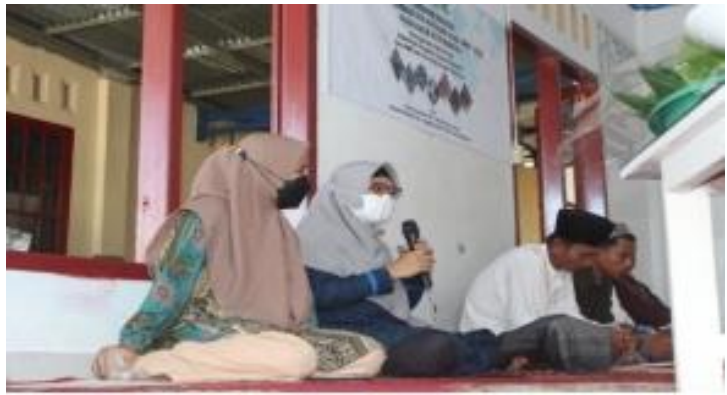

Gambar 1. Pemberian materi persiapan akreditasi lembaga

Selain kegiatan diatas, juga dilakukan pendampingan proses pengadministrasian lembaga, penjadwalan kegiatan LKSA dan penyiapan dokumen akreditasi LKSA. Dalam prosesnya, Tim Pengabdian Universitas Bengkulu berperan mendampingi Pengurus LKSA Guyub Rukun Kota Bengkulu dalam upaya mencapai tujuan kegiatan di atas. Tim Pengabdian kadang memberikan contoh kegiatan, menemani proses pengurus LKSA belajar melakukan kegiatan pengadministrasian, seperti pembuatan jadwal kegiatan anak-anak warga binaan, dan juga jadwal menu makanan warga binaan LKSA Guyub Rukun. Selain itu, terkadang Tim Pengabdian juga memfasilitasi atau menjadi penghubung antara LKSA dengan pihak-pihak lain yang terkait dengan pelaksanaan akreditasi lembaga, seperti Dinas Sosial Kota Bengkulu, Dinas Sosial Provinsi Bengkulu, Kementerian Sosial dan pihak lain yang terkait. Gambar 2 dan 3 berikut ini menunjukkan proses pendampingan Tim Pengabdian kepada Pengurus LKSA Guyub Rukun.

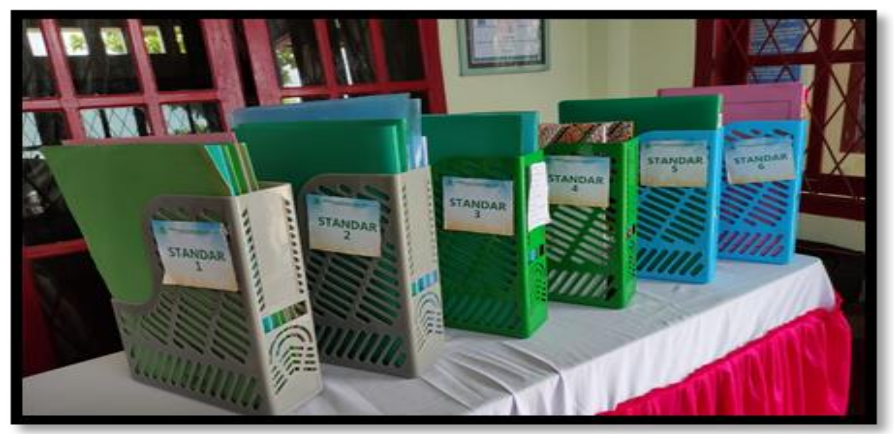

Gambar 2. Kelengkapan Akreditasi Standar 1-6 


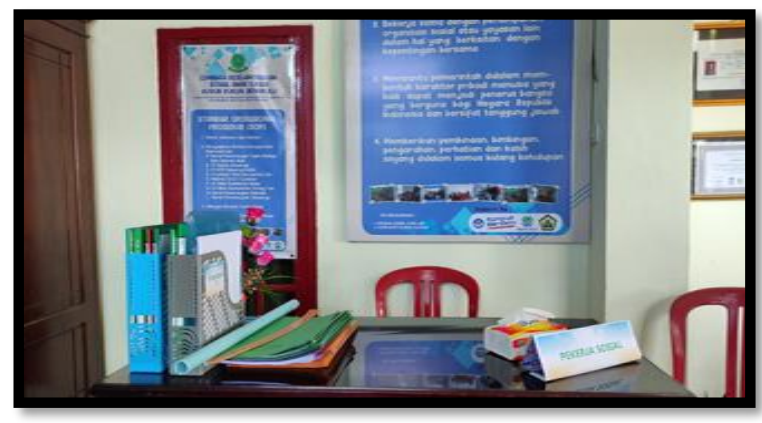

Gambar 3. Pendampingan kelengkapan akreditasi Lembaga

Kegiatan ain yang dilakukan dalam pengabdian ini adalah pendampingan proses pelaksanaan akreditas LKSA. Proses akreditasi ini dilakukan secara online pada hari Selasa 19 Oktober 2021, dimana Ketua LKSA Guyub Rukun melakukan presentasi dan diskusi dengan Tim Akreditasi Kementerian Sosial Republik Indonesia. Dalam kegiatan tersebut, dijelaskan 6 standar akreditasi, sebagaimana yang termuat dalam Instrumen Akreditasi LKS Anak dalam Panti tahun 2020 yang dikeluarkan oleh Badan Akreditasi Lembaga Kesejahteraan Sosial (2020), meliputi standar 1 (pelayanan terhadap warga binaan), standar 2 (proses pelayanan praktek pekerja sosial), standar 3 (manajemen organisasi), standar 4 (sumber daya manusia), standar 5 (sarana dan prasarana, dan standar 6 (hasil pelayanan lembaga).

Proses akreditasi tersebut dimulai dengan penjelasan sejarah pendirian LKSA Guyub Rukun, sarana prasarana yang tersedia dan kapasitas anak asuh yang sekarang mencapai 34 orang anak terdiri dari 15 orang anak laki-laki dan 19 orang anak perempuan. Dalam kegiatan tersebut juga dijelaskan bukti-bukti kelengkapan administrasi baik lembaga maupun pencatatan proses pengasuhan, yang secara fisik laporan tersebut dikirimkan melalui internet setelah proses online dilakukan sebagai bagian tak terpisahkan dalam proses akreditasi LKSA Guyub Rukun. Gambar 4 berikut ini menggambarkan proses akreditasi secara online.

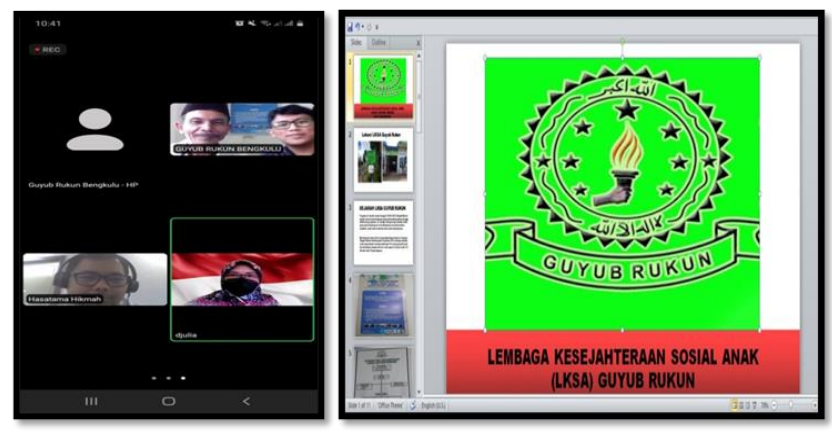

Gambar 4. Dokumentasi proses akreditasi lembaga
Pendampingan Tim Pengabdian Universitas Bengkulu dalam proses akreditasi LKSA Guyub Rukun ini diakhiri dengan kegiatan evaluasi bersama, yang dilakukan bersamaan dengan perayaan Maulid Nabi Muhammad SAW pada hari Rabu 20 Oktober 2021. Dalam kesempatan tersebut, Bapak Siswanto menyatakan: "Saya selaku Ketua LKSA Guyub Rukun, mengucapkan banyak terima kasih kepada Tim Pengabdian Universitas Bengkulu yang berkenan bersusah payah mendampingi proses akreditasi LKSA, semoga LKSA Guyub Rukun mendapatkan penilaian yang baik, dan tentu saja dapat meningkatkan pelayanannya bagi anak-anak binaan"

Dalam kesempatan tersebut, ketua Tim Pengabdian juga menyampaikan bahwa "LKSA Guyub Rukun ini merupakan rumah bersama bagi segenap pengurus lembaga dan tentu saja juga bagi anak-anak warga binaan. Oleh karena itu melalui proses akreditasi, semoga rumah bersama ini sama sama kita jaga, sama-sama kita tingkatkan pelayanannya sehingga dapat meningkatkan kesejahteraan hidup bersama."

Hal ini sesuai dengan pernyataan Anwar Sitepu (2020), bahwa Urgensi lembaga di bidang kesejahteraan sosial harus dimaknai sebagai upaya pemerintan dan negara menjamin keselamatan masyarakat yang terlibat dalam proses pelayanan sosial lembaga tersebut, sebagaimana ditegaskan dalam Pembukaan Undang-Undang Dasar 1945.

Lebih khusus lagi, pembentukan lembaga kesejahteraan sosial dan proses akreditasi, pada dasarnya merupakan upaya untuk memberikan perlindungan sosial bagi anak-anak, yang merupakan salah satu dari 5 elemen perlindungan sosial sebagaimana disampaikan oleh Asian Development Bank (ADB), bahwa perlindungan sosial merupakan sekumpulan kebijakan dan program yang dirancang untuk menurunkan kemiskinan dan kerentanan melalui upaya peningkatan dan perbaikan kapasitas penduduk dalam melindungi diri mereka dari bencana dan kehilangan pendapatan. ADB membagi perlindungan sosial kedalam 5 elemen, yaitu: 1) pasar tenaga kerja (labor markets), 2) asuransi sosial (social insurance), 3) bantuan sosial (social assistance), 4) skema mikro dan area based untuk perlindungan komunitas setempat, 5) perlindungan anak (child protection) (Bambang Rustanto: 2014).

Hal ini juga sesuai dengan makna perlindungan sosial juga merupakan perangkat kebijakan dan program yang dirancang untuk membantu dan melindungi anggorta masyarakat dari berbagai risiko dalam kehidupannya, baik yang timbul dari dirinya maupun yang timbul dari 
lingkungannya (Edi Suharto: 2009). Oleh karena itu dalam proses akreditasi pelayanan terhadap warga binaan menjadi salah satu aspek penilaian utama, mengingat anak-anak mempunyai kerentanan dalam pergaulan sosialnya baik di dalam panti, disekolah maupun dalam keluarganya.

Berdasarkan monitoring dan evaluasi yang dilaksanakan, baik dalam rangka kegiatan pengabdian masyarakat Universitas Bengkulu, maupun berdasarkan hasil proses akreditasi secara online yang telah dilakukan LKSA Guyub Rukun, maka Tim Pengabdian memberikan berbagai saran sebagai berikut:

Kepada Pengurus LKSA Guyub Rukun: a) Sesuai rekomendasi Tim Asesor akreditasi dari Kementerian Sosial, LKSA Guyub Rukun perlu membuat dan membangun sistem data dan informasi secara komputerisasi. Berbagai data lembaga sepereti profil klien, sarana prasarana LKSA, laporan kegiatan dan lain-lain data perlu dikelola dengan menggunakan komputer sehingga memudahkan pengurus dan pihak lain untuk melihat dan menganalisa kegiatan lembaga. Oleh karena itu, LKSA Guyub Rukun perlu mempersiapkan perangkat komputer sekaligus menyiapkan sumber daya manusia yang nanti mengelola komputer tersebut. b) Sesuai rekomendasi Tim Asesor akreditasi dari Kementerian Sosial, LKSA Guyub Rukun perlu membuat media informasi dengan menggunakan media sosial seperti Facebook dan instagram atau yang lebih bagus lagi membuat website lembaga. Pembuatan media informasi ini perlu dibarengi dengan penyiapan sumber daya manusia yang akan mengelola media informasi tersebut. Oleh karena itu, kedepan LKSA perlu memilih dan menetapkan siapa pengelola media informasi lembaga, sekaligus melatihketerampilannya.

Kemudian, Kepada Dinas Sosial Kota Bengkulu dan Dinas Sosial Provinsi Bengkulu juga disarankan agar secara rutin melainkan monitoring dan pembinaan kepada LKSA yang ada d Kota. Bengkulu, sehingga terbangun jejaring kerja yang kuat dalam perlindungan anak.

\section{KESIMPULAN}

Pengelolaan suatu lembaga, seperti LKSA Guyub Rukun, selalu diupayakan untuk sebesar-besarnya manfaat bagi anak-anak warga binaan. Oleh karena itu berbagai kegiatan yang dilakukan di dalamnya harus dikelola secara sistematis, komprehensif dan berkelanjutan. Berdasarkan uraian tersebut, maka kegiatan pengabdian masyarakat Universitas Bengkulu tahun 2021 ini merupakan salah satu upaya untuk meningkatkan kapasitas manajemen LKSA 34
Guyub Rukun, khususnya dalam menghadapi proses akreditasi lembaga kesejahteraan sosial anak. Akreditasi pada dasarnya merupakan penilaian atas kesiapan LKSA dalam membina anak-anak binaannya. Proses akreditasi tersebut meliputi penilaian terhadap 6 standar akreditasi, meliputi: standar 1 (pelayanan terhadap warga binaan), standar 2 (proses pelayanan praktek pekerja sosial), standar 3 (manajemen organisasi), standar 4 (sumber daya manusia), standar 5 (sarana dan prasarana, dan standar 6 (hasil pelayanan lembaga).

\section{UCAPAN TERIMAKASIH}

Tim Pengabdian mengucapkan banyak terima kasih kepada pihak Fakultas Ilmu Sosial dan Ilmu Politik (FISIP) Universitas Bengkulu yang telah memfasilitasi pendanaan kegiatan pengabdian, dan ungkapan terima kasih kepada segenap pengurus dan warga binaan LKSA Guyub Rukun, yang telah berpartisipasi aktif dalam kegiatan pengabdian, sehingga proses akreditasi lembaga terlaksana dengan lancar, bahkan telah mendapatkan hasil akreditasi dengan penilaian baik (B).

\section{DAFTAR PUSTAKA}

Grindle, MS.,(editor), 1997, Mendapatkan Pemerintahan yang Baik : Pengembangan Kapasitas di Sektor Publik Negara berkembang, MA: Institut Harvard untuk Pengembangan Internasional

Hardjanto Imam, 2006, Pembangunan Kapasitas Lokal (Local Capacity Building), Malang, Program Pascasarjana Universitas Brawijaya

Milen Anni , 2004, Pegangan Dasar Pengembangan Kapasitas. Diterjemahkan secara bebas, Yogyakarta, Pondok Pustaka Jogja

Rustanto Bambang, 2014, Sistem Perlindungan Sosial di Indonesia, Bandung, STKS Press

Suharto Edi, 2009, Kemiskinan dan Perlindungan Sosial di Indonesia (Menggagas Model Jaminan Sosial Universal Bidang Kesehatan), Bandung, CV Alfa Beta

Sitepu Anwar, 2020, Urgensi Akreditasi Lembaga Di Bidang Kesejahteraan Sosial, Sosioinforma, Vol 6, No 1 (2020)

Wijayanti Retno, Rengga Aloysius, Santoso R Slamet, 2015, Implementasi Standar Pelayanan Berbasis Lembaga Kesejahteraan Sosial Anak (LKSA) Oleh Dinas Sosial, Pemuda, dan Olah Raga Kota Semarang, Journal Of Public Policy and Management Review , Vol 4, Nomor 2 Tahun 2015

Kementerian Sosial RI, 2012, Peraturan Menteri Sosial RI Nomor 17 Tahun 2012 tentang Akreditasi Lembaga Kesejahteraan Sosial

Badan Akreditasi Lembaga Kesejahteraan Sosial, (2020), Instrumen Akreditasi LKS Anak dalam Panti tahun 2020. Jakarta: BALKS.

Profil Lembaga Kesejahteraan Sosial Anak (LKSA) Guyub Rukun Kota Bengkulu tahun 2021 